REVIEW PAPER

\title{
BIOACTIVE COMPOUNDS AND ETHNOMEDICINAL USES OF Syzygium cumini (L.) SKEELS - A COMPREHENSIVE REVIEW
}

\author{
RUCHI SHARMA ${ }^{1}$, KHYATI OBEROI ${ }^{1}$, KANIKA SHARMA ${ }^{1}$, RUPAK NAGRAIK ${ }^{1}$, DINESH \\ KUMAR $^{1}$, AVINASH SHARMA $^{1}$, SOMESH SHARMA ${ }^{1 *}$ \\ ${ }^{I}$ School of Bioengineering \& Food Technology, Shoolini University of Biotechnology and \\ Management Sciences, Solan, Himachal Pradesh, India, 173229 \\ *Corresponding author: someshsharma@shooliniuniversity.com
}

Received on 23 April 2020

Revised on 6 July 2020

\begin{abstract}
Syzygium cumini (S. cumini) is an underutilized fruit of tropical and subtropical regions with various bioactive compounds distributed in all parts of the plant. The fruit and its by-products, such as seeds, have both nutritional and medicinal value. However, fruit and seeds have not been fully considered as potential functional food ingredients to develop foods with promising health benefits. Based on the available information in the literature, fruit and seed are rich in phytochemicals, such as myricetin, oxalic acid, gallic acid, citronellol, cyanidin diglucoside, hotrienol, phytosterols, flavonoids, carotenoids and polyphenols as well as micronutrients. In addition, they were reported to possess several beneficial health properties. Further, research in this area would provide valuable information for their potential utilization as functional food ingredients. This review presents comprehensive information about the bioactive compounds and nutraceutical properties of $S$. cumini fruit and seeds, as well as the potential of using them as functional food ingredients
\end{abstract}

Keywords: Syzygium cumini, fruits, Seeds, bioactive compounds, health benefit, functional food

\section{Introduction}

The genus Syzygium is derived from the Greek word Syzygos meaning yoked together (Janick and Paull, 2008). It is mainly distributed in the Old-World tropics from Africa to the West Pacific with a major concentration in Malaysia (Parnell et al., 2007). Till date, around 55 taxa of Syzygium have been reported in India (Shareef et al., 2012) with the highest concentration of 49 taxa in the Western Ghats (Shareef et al., 2010). Syzygium cumini is one among the species and belongs to the family Myrtaceae, which includes 150 genera and above 3600 species (Saleem et al., 2016). Global production of Syzygium cumini is about 13.5

https://doi.org/10.35219/foodtechnology.2020.1.14 
million tons per annum (Chhikara et al., 2018) out of which India contributes about 5.4\% (Raza et al., 2015). It is an underutilized fruit of tropical and subtropical regions and contains phytoconstituents e.g. anthocyanins, flavonoids, steroids, polyphenols, terpenoids etc. in worthy amounts. Other associated species of the plant are Syzygium cumini (L.) Druce, Eugenia jambolana Lam., Syzygium jambolanum DC. It is commonly known by the name of jambolan, java plum, Jamun, Indian blackberry, kalajam, mahajambu, jambul, purple plum. The fruit is an oval-shaped berry and has been considered as "Fruit of Gods" in Hindu myths (Jagetia, 2017). The original home of Syzygium cumini is India, distributed throughout India, in the forest up to $1800 \mathrm{~m}$ height. Today, these trees are found throughout the Asian subcontinent, Eastern Africa, South America, Madagascar, Java, Florida and Hawaii (USA). It is well known for its medicinal and curative properties like antidiuretic, antimicrobial, hepatoprotective, antifungal, antioxidant and various other properties. The nutritional and phytochemical content of fruits depends on the maturity level, variety, climatic conditions, agricultural practices, and post-harvest handling and processing. The purple to black colour of the fruit is due to the presence of anthocyanin and is responsible for high antioxidant potential (Panghal et al., 2018). The active principles present in medicinal plants are used for the healing purpose against a variety of diseases from the beginning of civilization. In Unani medicine, Syzygium cumini is used as a liver tonic, strengthens the teeth and gums, enrich the blood, and deworm against ringworm infection of the head (Damasceno et al., 2002). Stem bark, dried seeds and root bark decoction are used to treat diarrohea, dysentery and dyspepsia and further to cure asthma and bronchitis (Ranjan et al., 2011). The decoction of Syzygium cumini seeds relieves fatigue and strain. The fruit pulp is used to treat gingivitis, and haemorrhoids. Examples for the traditional use of Syzygium cumini in different regions of the world are given in Table 1. In Indian Ayurveda medicine, the aerial parts of Jamun have been used to cure sores in the mouth, colic, digestive illnesses, diarrhoea, dysentery, diabetes, pimples, piles, stomach ache, cancer (Jain, 1991) and act as a blood purifier. Fruit pulp with honey is administered to keep the body healthy, while its seed powder helps in clearing the skin blemishes and acne. The leaf juice is effective in the treatment of dysentery and skin disorders. Phytochemical constituents present in Syzygium cumini seed are used to treat diabetes, pharyngitis, spleenopathy, urethrorrhea due to the presence of gallic acid, ellagic acid, corilagin, 3, 6-hexahydroxy diphenoylglucose,1-galloylglucose, 3galloylglucose, quercetin, $\beta$-sitoterol,4,6-hexahydroxydiphenoyl glucose (Kumawat et al., 2018). The aim of this review is to provide literature covering botanical, phytochemical, pharmacological and health aspects of Syzygium cumini along with its utilization as a food fortification tool.

\section{Morphology characteristics}

Syzygium cumini is a perennial tree with a 30 meter height and stems up to 15 meters (Singh and Navneet, 2018) and is a foliaceous tree with greyish-brown bark. It is a cross-pollinated tree and bears fruits up to 100 years. Brown dyes and a gum 
Kino are obtained from the wood which is whitish and durable. The leaves are 5-25 $\mathrm{cm}$ long and 2.5-10 $\mathrm{cm}$ wide with a turpentine smell and are leathery, oblongovate.

Table 1. Traditional uses of Syzygium cumini (Region- wise).

\begin{tabular}{|c|c|c|c|}
\hline Region & $\begin{array}{l}\text { Parts } \\
\text { used }\end{array}$ & Mode of Use & References \\
\hline $\begin{array}{l}\text { Paraja tribe } \\
\text { (Odisha, } \\
\text { India) }\end{array}$ & Bark & $\begin{array}{l}\text { Paste is used to cure dysentery when taken orally } \\
\text { with water }\end{array}$ & $\begin{array}{l}\text { Tikadar et al., } \\
2017\end{array}$ \\
\hline India & Root & $\begin{array}{l}\text { Used to cure dysentery and diarrhoea when taken } \\
\text { twice daily with empty stomach }\end{array}$ & $\begin{array}{l}\text { Sen and Behra, } \\
2008\end{array}$ \\
\hline Brazil & Leaves & $\begin{array}{l}\text { Tea prepared from infusion/decoction of leaves } \\
\text { (taken orally) for treatment of diabetes }\end{array}$ & $\begin{array}{l}\text { Ayyanar et al., } \\
2008\end{array}$ \\
\hline $\begin{array}{l}\text { Southern } \\
\text { Brazil }\end{array}$ & Leaves & $\begin{array}{l}\text { Daily intake of } 2.5 \mathrm{~g} / \mathrm{L} \text { of leaves are used for } \\
\text { treatment of diabetes }\end{array}$ & $\begin{array}{l}\text { Ayyanar and } \\
\text { Babu, } 2012\end{array}$ \\
\hline Madagascar & Seeds & $\begin{array}{l}\text { Seeds are taken as an effective remedy for } \\
\text { stabilizing the impacts of diabetes }\end{array}$ & $\begin{array}{l}\text { Ayyanar and } \\
\text { Babu, } 2012\end{array}$ \\
\hline $\begin{array}{l}\text { Sinhal (Sri } \\
\text { lanka) }\end{array}$ & Bark & $\begin{array}{l}\text { Bark decoction is used in treating diabetes mellitus } \\
\text { in Ayurveda medicine }\end{array}$ & $\begin{array}{l}\text { Perera et al., } \\
2017\end{array}$ \\
\hline- & Leaves & $\begin{array}{l}\text { Used as a cleaning agent that effectively } \\
\text { strengthens teeth and gingiva }\end{array}$ & $\begin{array}{l}\text { Kumar et al., } \\
2009\end{array}$ \\
\hline $\begin{array}{l}\text { Kani(Tamil } \\
\text { nadu, India) }\end{array}$ & $\begin{array}{l}\text { Leaf } \\
\text { juice }\end{array}$ & Leaf juice is mixed with honey or cow milk & $\begin{array}{l}\text { Ayyanar et al., } \\
2008\end{array}$ \\
\hline Surinam & Leaves & $\begin{array}{l}\text { Women's use leaves to contract the vagina after } \\
\text { delivery }\end{array}$ & $\begin{array}{l}\text { Ramya et al., } \\
2012\end{array}$ \\
\hline $\begin{array}{l}\text { Pawi, Lakher } \\
\text { (Northeast } \\
\text { India) }\end{array}$ & $\begin{array}{l}\text { Leaves } \\
\text { juice }\end{array}$ & $\begin{array}{l}\text { Juice of leaves is used as an antidote in Opium } \\
\text { poisoning }\end{array}$ & $\begin{array}{l}\text { Ayyanar et al., } \\
2013\end{array}$ \\
\hline $\begin{array}{l}\text { Maharashtra } \\
\text { tribe (India) }\end{array}$ & Leaves & $\begin{array}{l}\text { Oral intake of leaves for } 2-3 \text { days for jaundice } \\
\text { treatment among adults and children }\end{array}$ & $\begin{array}{l}\text { Ayyanar et al., } \\
2013\end{array}$ \\
\hline- & Leaf ash & For strengthening teeth and gums leaf ash is used & $\begin{array}{l}\text { Ramya et al., } \\
2012\end{array}$ \\
\hline- & Fruit & $\begin{array}{l}\text { Jamun is used as semen-producer and is hematinic } \\
\text { and is used as thermos regulant in Siddha } \\
\text { medication }\end{array}$ & $\begin{array}{l}\text { Ramya et al., } \\
2012\end{array}$ \\
\hline Philippines & Bark & The bark is utilized for diabetes & $\begin{array}{l}\text { Bandiola et al., } \\
2017\end{array}$ \\
\hline $\begin{array}{l}\text { Goa (India) } \\
\text { and } \\
\text { Philippines }\end{array}$ & Fruit & Wine is produced which resembles Port & $\begin{array}{l}\text { Swami et al., } \\
2012\end{array}$ \\
\hline $\begin{array}{l}\text { Jhabua } \\
\text { District } \\
\text { (Madhya } \\
\text { Pradesh, } \\
\text { India) }\end{array}$ & Bark & The bark is used for dysentery and diarrhoea & $\begin{array}{l}\text { Rout and } \\
\text { Panda, } 2017\end{array}$ \\
\hline
\end{tabular}


Flowering starts in the month of March to April and the fruit develops in May or June and is initially green in color, then turns pink and finally purple in color. Flowers are scented, greenish-white, round or oblong in shape and are in clusters of just a few or 10 to 40 . The fruits are dark purple, black, luscious, fleshy with edible berries weighing individually $2-5 \mathrm{~g}$ at the time of maturity, 1.5 to $3.5 \mathrm{~cm}$ long and contains a large single, oblong, green or brown seed upto $4 \mathrm{~cm}$ long and some seedless. The skin of the fruit is glossy and smooth with purple or white pulp, discolored bark, rough and cracked on the lower part of the trunk (Bijauliya et al., 2017 ). Fresh seeds contain $20-80 \%$ of the total fruit weight with $6 \%$ seed coat and $94 \%$ cotyledons (Sivasubramaniam and Selvarani, 2012). Depending on the fruit size there are two varieties of Syzygium cumini; small and big, the smaller variety is round and has sweet flesh with low content of acids, tannins and anthocyanins. The large seed is oval and has acidic flesh with a high content of acids, tannins and anthocyanins (Roy et al., 2013). The different varieties of Syzygium cumini grown in the Indian subcontinent are represented in Table 2.

Table 2. Different varieties of Syzygium cumini and their characteristics

\begin{tabular}{ll}
\hline \multicolumn{1}{c}{ Variety } & \multicolumn{1}{c}{ Characteristics } \\
\hline Ra Jamun & $\begin{array}{l}\text { Oblong, large, juicy, sweet, deep purple with a small seed, ripens } \\
\text { in June-July } \\
\text { Badama }\end{array}$ \\
Large and juicy \\
Small, Acidic, ripens in the middle of June \\
Jathi & Ripens in May-June \\
Ashada & Ripens in June-July \\
Bhado & Ripens in August \\
Goma Priyanka & Ripens in fourth week of May \\
GJ - 8 & Ripens in second week of June \\
GJ - 19 & Ripens in first week of June \\
GJ - 23 & Ripens in middle of June \\
GJ - 40 & Ripens in fourth week of June \\
Narendra Jamun 6 & Oblong \\
Krian Duat & Purple and white flesh \\
Paras & Large sized sweet and juicy fruits. \\
Konkan Bahdoli & Bold, small seeds \\
\hline
\end{tabular}

Source: Adapted from Potential of commercial cultivation of Jamun (Anonymous, 2013)

\section{Phytochemical constituents of Syzygium cumini}

Syzygium cumini (L.) is one of the fruits with high nutritive value. In the fruit processing industry, edible portions of the fruits are processed into valuable products such as puree, canned slices, juice, jam, pickles and results in high amounts of waste materials such as peels, seeds, stones, and oilseed meals which are discarded as waste (El-Safy et al., 2012). But seeds are also a promising source 
of useful components because of their biochemical characteristics (Table 3). Different researchers have evaluated biochemical components present in fruit and found these to be of high medicinal value due to the presence of glycosides, flavonoids, terpenoids, alkaloids and phenols.

Table 3. Biochemical composition of Syzygium cumini seed

\begin{tabular}{|c|c|c|}
\hline Component & Quantity & Reference \\
\hline Moisture (\%) & $3.21-53$ & $\begin{array}{l}\text { Dagadkhair et al., 2017; Ghosh et al., } \\
\text { 2016; Harine and Janapriya, 2018; Ayya } \\
\text { et al., 2015; Raza et al., 2015; Mathur, } \\
\text { 2015; Kaur et al., } 2018\end{array}$ \\
\hline Protein $(\%)$ & $1.97-8.5$ & $\begin{array}{l}\text { Dagadkhair et al., 2017; Ghosh et al., } \\
\text { 2016; Harine and Janapriya, 2018; Ayya } \\
\text { et al., 2015; Raza et al., 2015; Prajatka et } \\
\text { al., 2016; Mathur, 2015; Kaur } \text { et al., 2018; } \\
\text { Anjali et al., 2017; Ranjan et al., 2011; } \\
\text { Binita et al., } 2017\end{array}$ \\
\hline Fat (\%) & $\begin{array}{l}0.65- \\
4.86\end{array}$ & $\begin{array}{l}\text { Dagadkhair et al., 2017; Ghosh et al., } \\
\text { 2016; Harine and Janapriya, 2018; Ayya } \\
\text { et al., 2015; Raza et al., 2015; Prajatka et } \\
\text { al., 2016; Kaur et al., 2018; Anjali et al., } \\
2017\end{array}$ \\
\hline Ash $(\%)$ & $\begin{array}{l}1.5- \\
21.72\end{array}$ & $\begin{array}{l}\text { Dagadkhair et al., 2017; Ghosh et al., } \\
\text { 2016; Harine and Janapriya, 2018; Ayya } \\
\text { et al., 2015; Raza et al., 2015; Prajatka et } \\
\text { al., 2016; Kaur et al., } 2018\end{array}$ \\
\hline Fibre $(\%)$ & $\begin{array}{l}1.21- \\
16.9\end{array}$ & $\begin{array}{l}\text { Ghosh et al., 2016; Harine and Janapriya, } \\
\text { 2018; Ayya et al., 2015; Raza et al., 2015; } \\
\text { Prajatka et al., 2016; Kaur et al., 2018; } \\
\text { Anjali et al., 2017; Ranjan et al., 2011; } \\
\text { Binita et al., } 2017\end{array}$ \\
\hline Carbohydrates (\%) & $\begin{array}{l}6.05- \\
89.68\end{array}$ & $\begin{array}{l}\text { Dagadkhair et al., 2017; Ghosh et al., } \\
\text { 2016; Harine and Janapriya, 2018; Ayya } \\
\text { et al., 2015; Kaur et al., 2018 }\end{array}$ \\
\hline Ascorbic acid (\%) & $\begin{array}{l}1.84- \\
35.75\end{array}$ & $\begin{array}{l}\text { Dagadkhair et al., 2017; Ghosh et al., } \\
2016\end{array}$ \\
\hline Iron (mg) & $\begin{array}{l}1.25- \\
18.62\end{array}$ & $\begin{array}{l}\text { Ghosh et al., 2016; Harine and Janapriya, } \\
\text { 2018; Ayya et al., } 2015\end{array}$ \\
\hline Total flavonoids (TF) (mg/g) & 6.00 & Prajatka et al., 2016; Hossain et al., 2017 \\
\hline Total phenolic content (TPC) (mg/g) & 78.29 & Prajatka et al., 2016; Hossain et al., 2017 \\
\hline $\begin{array}{l}\text { (2,2'-azino-bis (3-ethylbenzothiazoline-6- } \\
\text { sulphonic acid)) (ABTS) }(\mu \mathrm{M} / \mathrm{g})\end{array}$ & 118.61 & Prajatka et al., 2016 \\
\hline
\end{tabular}

Earlier studies revealed that the extracts also play a great role in the extraction of phytochemicals from seed, leaves, bark, flower, fruit and even roots. Different phytochemicals such as 1-galloylglucose, 3-galloylglucose, gallic acid, 3,6hexahydroxy diphenoyl glucose, ellagic acid, corilagin, quercetin, $\beta$-sitoterol, 4,6hexahydroxydiphenoyl glucose, ferulic acid, guaicol, resorcinol, $p$-coumaric acid, catechin, epicatechin, quercetin, caffeic acid, tannic acid were reported from seed (Kumawat et al., 2018; Balyan and Sarkar, 2017; Mathur, 2015). 
The leaves are reported to contain mearsetin, quercetin, myricetin, gallitanins, essential oil (terpenes, 1-limonene and dipentene), monoterpenoid terpinene, terpenolene, borbeneol, polyphenol (gallic acid, methylgallate, kaempferol, ellagic acid, ellagitannin, nilocitin, myrecetin 3-0-D- glucaronopyranoside, 3-0-ß Dglucuronopyranoside, myricetin 3-O-4-Acetyl-L-rhamnopyranoside), terpineol and eugenol (Satpute and Vanmare, 2018). The root extract showed the presence of flavonoid glycosides, isorhamnetin 3-O-rutinoside). Malvidin-3-laminaribioside, citric acid, mallic acid, gallic acid, anthocyanins delphinidin-3-gentiobioside, petunidin-3 gentiobioside, cyanidin diglycoside, petunidin and malvidin are reported from the fruit extract (Bijauliya et al., 2017). Myricetin-3-L-arabinoside, quercetin-3-D-galactoside, kaempferol, quercetin, myricetin, isoquercetin, dihydromyricetin, oleanolic acid, acetyl oleanolic acid, eugenol-triterpenoid A, eugenol-triterpenoid B are reported in the flower extract (Sehwag and Das, 2014). The bark extract contains $\beta$-sitosterol, eugenin and fatty acid ester of epifriedelanol, betulinic acid, friedelin, epi-friedelanol, quercetin kaempferol, myricetin, gallic acid and ellagic acid bergenins, flavonoids and tannins (Sehwag and Das, 2014). The various bioactive chemicals along with their structure are presented in Figure 1.

\section{Pharmacological activities of Syzygium cumini fruit and seeds}

The extracts of different plant parts and the isolated compounds of Syzygium cumini have been evaluated for antimicrobial, antibacterial, anticancer, antimicrobial, antidiabetic, hepatoprotective, antifungal, anti-diuretic and antioxidant activities. The health benefits of Syzygium cumini (L.) Skeels seed extracts are represented in Table 4.

\section{Antimicrobial Activity}

The methanolic extracts of Syzygium cumini (Linn.) seeds show $20.03 \mathrm{~mm}$ zone of inhibition against MTCC 2413 Bacillus subtilis at a concentration of $25 \mathrm{mg} / \mathrm{ml}$ using agar well diffusion method (Yadav et al., 2017). The antimicrobial activity of Syzygium cumini seed powder with 4 different formulations such as sample A (collected from a local manufacturer), sample B (polyherbal formulation with Syzygium cumini seed powder), sample C and D (formulations from diverse manufacturers) were determined. The results revealed that Syzygium cumini seed powder from a local manufacturer and formulation with powder from other manufacturers had good activity against Candida albicans (Chitnis et al., 2012). The methanol, ethanol and acetone extracts of Eugenia jambolana (Lam.) seeds have significant antimicrobial activities against Streptococcus aureus, Shigella, Pseudomonas and Salmonella isolates with an inhibition zone of 11 to $35 \mathrm{~mm}$ (Ogato et al., 2015).

\section{Antibacterial Activity}

Antibacterial activity is the ability of a substance to inhibit or kill bacterial cells. Medicinal plants such as Allium sativum, Azadirachta indica, Cordia dichotoma, Holoptelea integrifolia, Ocimum sanctum, Syzigium cumini, Wild Himalayan fig and Trigonella foenum graecum possess antibacterial properties (Imran et al., 
2017; Kumari et al., 2017). Aqueous extract of Syzygium cumini leaf showed lowest minimum inhibitory concentration (MIC) of $10 \mu \mathrm{L}$ in the case of Proteus mirabilis and Shigella flexneri and highest minimum inhibitory concentration (MIC) of $50 \mu \mathrm{L}$ in case of Staphylococcus aureus, Shigella sonnei (Satish et al., 2008). Crude methanol and aqueous extracts of the leaves of Syzygium cumini were assessed against Gram positive and negative bacterial strains using the disc diffusion method and the maximum zone of inhibition $22 \mathrm{~m}$ was obtained using methanol extract against Gram negative bacteria (Gowri and Vasantha, 2010). In another study methanol extract of Syzygium cumini leaf showed an inhibition zone of $32 \mathrm{~mm}$ against Staphylococcus aureus as a comparison to standard drug Chloramphenicol which is $26 \mathrm{~mm}$ (Kumar et al., 2014).
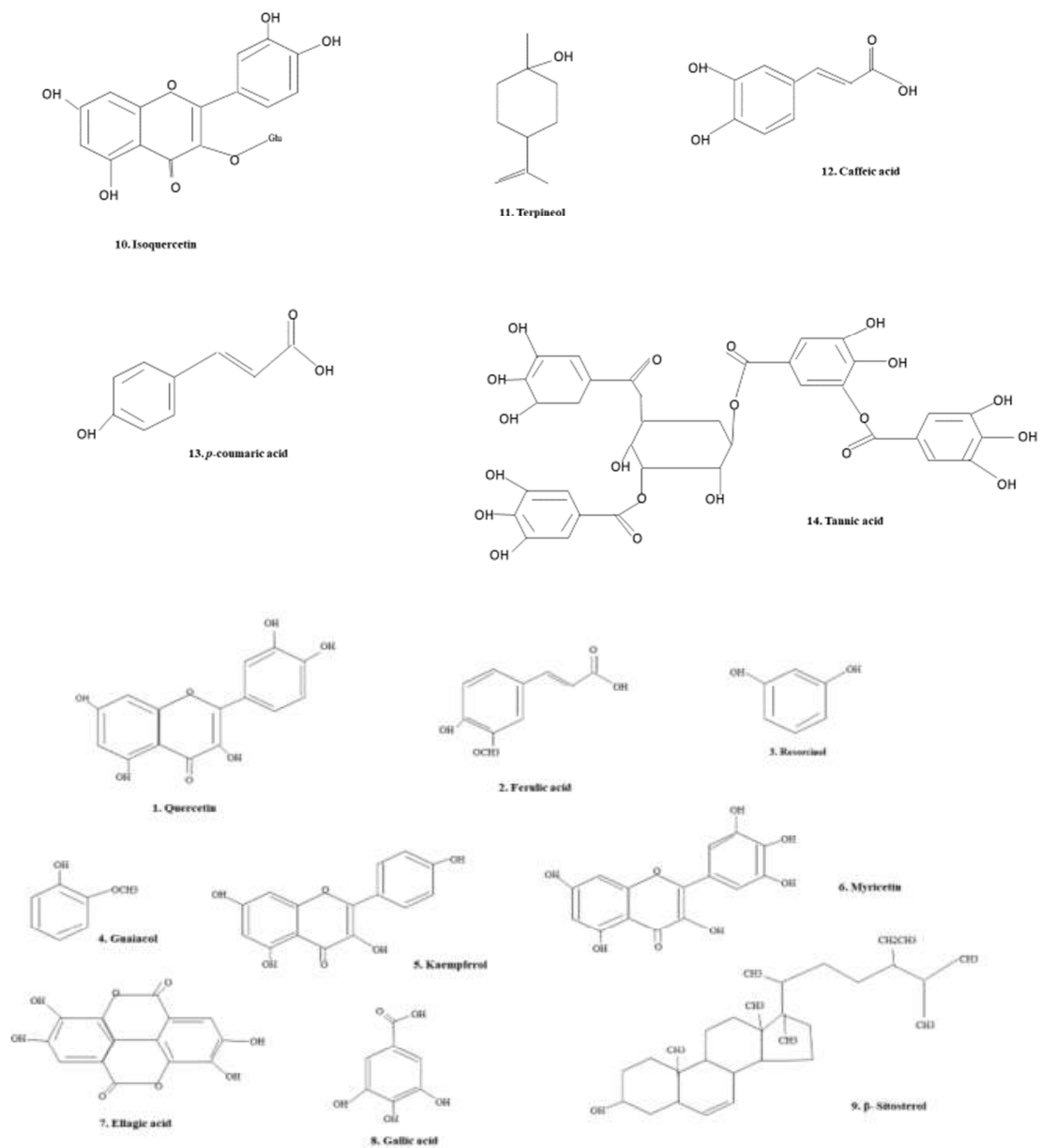

Figure 1. Biologically active compounds reported from Syzygium cumini 
The Acetylsalicylic acid extract of Syzygium cumini leaves showed a $24 \mathrm{~mm}$ zone of inhibition against Gram negative bacteria Vibrio parahimolyticus (Julie et al., 2017). Petroleum and ethanolic extracts of leaves showed a maximum zone of inhibition $(8-25 \mathrm{~mm})$ against the drug resistant strains of Streptococcus aureus and E. coli (Imran et al., 2017). Antibacterial activity of the aqueous and alcoholic extracts of stems was observed against two Gram-positive bacteria (Bacillus amyloliquefaciens and Staphylococcus aureus) and two Gram-negative bacteria (Escherichia coli and Pseudomonas aeruginosa) by agar well diffusion method and the results revealed that the alcoholic extract showed maximum antibacterial activity (Sharma et al., 2017). The fruit juice of Syzygium cumini showed inhibition of 1 to 6 logs against enteric pathogens Salmonella typhimurium, Shigella Flexneri and Staphylococcus aureus (Haque et al., 2017). Hence, from the earlier results, it can be concluded that every part of the plant has antibacterial activity when extracted with different solvents. Therefore, the plant has the potential to be used in nano-composite forms for application in different fields of applied sciences.

Table 4. Health benefits of Syzygium cumini (L.) Skeels seed extracts prepared using different solvents on living organism

\begin{tabular}{|c|c|c|c|c|c|}
\hline \multirow{2}{*}{$\begin{array}{l}\text { No } \\
1 .\end{array}$} & \multirow{2}{*}{$\begin{array}{r}\text { Activity } \\
\text { Antidiabetic }\end{array}$} & \multicolumn{2}{|c|}{ Extract type } & \multirow{2}{*}{$\begin{array}{l}\text { in vitro/ } \\
\text { animal model }\end{array}$} & \multirow{2}{*}{$\begin{array}{r}\text { Reference } \\
\text { Kumar, } 2008\end{array}$} \\
\hline & & $\begin{array}{l}\text { Methanol, } \\
\text { acetate }\end{array}$ & Ethyl & & \\
\hline & & Ethanol & & Rat & $\begin{array}{l}\text { Chaturvedi et al., } \\
2009\end{array}$ \\
\hline & & Chloroform & & Mice & Dusane et al., 2011 \\
\hline & & Methanol & & Rat & Mastan et al., 2009 \\
\hline & & Ethanol & & Rat & $\begin{array}{l}\text { Kasiappan et al., } \\
2005\end{array}$ \\
\hline 2. & Analgesic & $\begin{array}{l}\text { Methanol, } \\
\text { acetate }\end{array}$ & Ethyl & Mice & Kumar, 2008 \\
\hline \multirow[t]{3}{*}{3.} & $\begin{array}{l}\text { Anti-inflammatory } \\
\text { activity }\end{array}$ & $\begin{array}{l}\text { Methanol, } \\
\text { acetate }\end{array}$ & Ethyl & Mice & Kumar, 2008 \\
\hline & & $\begin{array}{l}\text { Methanol, } \\
\text { acetate }\end{array}$ & Ethyl & Rats & Kumar et al., 2008 \\
\hline & & Aqueous & & Human & $\begin{array}{l}\text { Ezekiel and } \\
\text { Heuertz, } 2015\end{array}$ \\
\hline \multirow[t]{2}{*}{4.} & Cardioprotective & Aqueous & & Rat & Patel et al., 2010 \\
\hline & & Methanol & & Rat & Mastan et al., 2009 \\
\hline \multirow[t]{2}{*}{5.} & Chemopreventive & Acetone & & Mice & Parmar et al., 2010 \\
\hline & & Aqueous, etl & & pBR322 & Arun et al., 2011 \\
\hline
\end{tabular}




\begin{tabular}{|c|c|c|c|c|}
\hline No & Activity & Extract type & $\begin{array}{c}\text { in vitro/ } \\
\text { animal model }\end{array}$ & Reference \\
\hline & & & DNA & \\
\hline & & Double distilled water & Mice & Goyal et al., 2010 \\
\hline \multirow[t]{4}{*}{6.} & $\begin{array}{l}\text { Neuro- } \\
\text { psychopharmacological }\end{array}$ & $\begin{array}{l}\text { Methanol/Ethyl } \\
\text { acetate }\end{array}$ & Mice & Kumar, 2008 \\
\hline & activity & $\begin{array}{l}\text { Ethyl acetate/ } \\
\text { methanol }\end{array}$ & Mice & Kumar et al., 2007 \\
\hline & & Chloroform & Rat & $\begin{array}{l}\text { Sehwag and Das, } \\
2014\end{array}$ \\
\hline & & Hydro-alcohol & Rat & $\begin{array}{l}\text { Sehwag and Das, } \\
2014\end{array}$ \\
\hline 7. & Gastroprotective & Ethanol & Rat & $\begin{array}{l}\text { Jonnalagadda et } \\
\text { al., } 2013\end{array}$ \\
\hline \multirow[t]{2}{*}{8.} & Heptoprotective & Methanol & Rat & $\begin{array}{l}\text { Sisodia and } \\
\text { Bhatnagar, } 2009\end{array}$ \\
\hline & & Ethanol & Rat & Islam et al., 2015 \\
\hline 9. & Antipyretic activity & $\begin{array}{l}\text { Methanol, Chloroform } \\
\text { extract }\end{array}$ & Rat & $\begin{array}{l}\text { Sehwag and Das, } \\
2014\end{array}$ \\
\hline 10. & Anticancer & $\begin{array}{l}\text { Ethyl acetate, } \\
\text { Methanol }\end{array}$ & $\begin{array}{l}\text { MCF-7 } \\
\text { breast cancer } \\
\text { cells }\end{array}$ & $\begin{array}{l}\text { Ruthurusamy et } \\
\text { al., } 2015\end{array}$ \\
\hline 11. & Radioprotective & Hydro-alcohol & Mice & Jagetia et al., 2005 \\
\hline \multirow[t]{2}{*}{12.} & Immunomodulatory & Aqueous & $\begin{array}{l}\text { Human } \\
\text { lymphocytes }\end{array}$ & Borges et al., 2017 \\
\hline & & Methanol & Mice & $\begin{array}{l}\text { Barh and } \\
\text { Vishwanathan } \\
2008\end{array}$ \\
\hline \multirow[t]{4}{*}{13.} & Antimicrobial & Methanol & $\begin{array}{l}\text { Bacillus } \\
\text { subtilis }\end{array}$ & Yadav et al., 2017 \\
\hline & & $\begin{array}{l}\text { Acetone, methanol, } \\
\text { ethanol }\end{array}$ & $\begin{array}{l}\text { S. aureus, } \\
\text { Pseudomonas } \\
\text { species and } \\
\text { Salmonella } \\
\text { species }\end{array}$ & Ogato et al., 2015 \\
\hline & & $\begin{array}{l}\text { Methanol, } \\
\text { acetate }\end{array}$ & $\begin{array}{l}\text { Gram } \\
\text { positive and } \\
\text { negative } \\
\text { bacteria }\end{array}$ & $\begin{array}{l}\text { Sehwag and Das } \\
(2014), \text { Kumawat } \\
\text { et al., } 2018\end{array}$ \\
\hline & & Ethyl acetate & Mice & Bag et al., 2012 \\
\hline
\end{tabular}




\begin{tabular}{|c|c|c|c|c|}
\hline No & Activity & Extract type & $\begin{array}{c}\text { in vitro/ } \\
\text { animal model }\end{array}$ & Reference \\
\hline & & $\begin{array}{l}\text { Dichloromethane } \\
\text { methanol }\end{array}$ & Candida & $\begin{array}{l}\text { Hofling et al., } \\
2010\end{array}$ \\
\hline \multirow[t]{5}{*}{14.} & Antibacterial & Methanol & $\begin{array}{l}\text { Vibrio } \\
\text { cholera, } \\
\text { Aeromonas } \\
\text { hydrphila, } \\
\text { Bacillus } \\
\text { subtilis }\end{array}$ & Jadhav et al., 2009 \\
\hline & & Methanol & $\begin{array}{l}\text { Proteus } \\
\text { vulgaris/ } \\
\text { Pseudomonas } \\
\text { aeruginosa }\end{array}$ & Mathur et al., 2011 \\
\hline & & Methanol/ ethanol & $\begin{array}{l}\text { Gram } \\
\text { positive/ } \\
\text { Gram } \\
\text { negative } \\
\text { bacteria }\end{array}$ & $\begin{array}{l}\text { Sharma et al., } \\
2012\end{array}$ \\
\hline & & Alcohol & E. coli & $\begin{array}{l}\text { Meshram et al., } \\
2011\end{array}$ \\
\hline & & Ethanol & $\begin{array}{l}\text { E. coli, } B . \\
\text { subtilis, } \quad P . \\
\text { aeruginosa } \\
\text { and S. aureus }\end{array}$ & Bhusari, 2014 \\
\hline
\end{tabular}

\section{Antifungal activity}

Antimycotic activity of plants remains largely unexplored and these days' interest has grown in studying antifungal activity from plant sources (Singh et al., 2017). The aqueous and methanolic extract of Eugenia jambolana (Lam.) seeds possesses antifungal activity against dermatophytic fungi Candida albicans and Tricophyton rubrum using agar diffusion method (Chandrasekaran and Venkatasalu, 2004). Kharat et al., 2005 also reported the plant effectiveness against the standard fungal culture of Fusarium oxysporum and Alternaria alternata which are responsible for various diseases in agriculture crops. Pant et al., 2014 administered that methanolic fruit extract of Syzygium cumini has excellent antifungal action against various pathogenic fungi Fusarium oxysporium, Rhizoctonia solani and Sclerotium rolfsii. Methanolic bark extract at a concentration of 5\% was highly effective against fungal species and was reported to reduce the fungal growth by $43 \%$ (Khan et al., 2016).

\section{Anti-arthiritic activity}

Arthritis is a chronic inflammatory disease in joints. The oral administration of petroleum ether extract of the plant stem bark in rats with a dose of $1000 \mathrm{mg} / \mathrm{kg}$ on 
complete freund's adjuvant induced arthritis showed high anti-rheumatic effect (Venkataramanan et al., 2016). Similarly, methanolic extract of the plant seeds showed anti-arthritis effect on adjuvant induced arthritis in rats when given at a dosage of 500mg/kg (Kumar et al., 2008; Arya et al., 2011).

\section{Chemopreventive activity}

In vitro anti breast cancer activity of methanol extract of Syzygium cumini fruit pulp against MCF-7 cell line was evaluated using the method of microculture tetrazolium (MTT) assay to evaluate the reduction of viability of cell cultures. The results showed that the cell viability was inhibited to different extents due to the presence of flavonoids, alkaloids, steroids in the extract (Tripathy and Pradhan, 2015). Hydro-alcoholic extract of Syzygium cumini seed ( $125 \mathrm{mg} / \mathrm{kg}$ body weight) possesses chemopreventive properties in the DMBA-induced and croton oil promoted skin carcinogenesis in Swiss albino mice by a significant reduction in cumulative numbers of papillomas and tumor incidence (75\%) (Parmar et al., 2010). The aqueous extract of Syzygium cumin seed $(25 \mathrm{mg} / \mathrm{kg}$ body weight/day) was effective in preventing benzo-a-pyrene (BaP)-induced forestomach carcinogenesis in swiss albino mice and had reduced the tumour incidence, tumour burden and the cumulative number of gastric carcinomas (Goyal et al., 2010). Oral administration of $125 \mathrm{mg}$ extract $/ \mathrm{kg}$ body weight/day of Syzygium cumini seeds during pre-initiation or post initiation reduced the aggregate numbers of papillomas, the tumour incidence and increased the average latency period when compared with the control group and it was concluded that extract has the potential to modulate biochemical and histopathological status during skin carcinogenesis. Further, there was a significant reduction in lipid peroxidation and elevation in the activities of enzymatic antioxidants, non-enzymatic antioxidants and protein levels (Parmar et al., 2011). In- vitro inhibitory effect of Syzygium cumini extract on two cervical cell lines (HeLa and $\mathrm{SiHa}$ ) was also observed. The crude extract was reported to be more effective in growth inhibition and apoptosis with growth inhibition of $33.7 \%$ and $24.4 \%$ in HeLa and $\mathrm{SiHa}$ cells at its highest concentration $(100 \%)$ in MTT assay and the methanolic extract $(80 \% \mathrm{v} / \mathrm{v})$ showed an apoptotic index of $20.5 \%$ and $16.1 \%$ (Barh and Vishwanath, 2008).

\section{Antianaemic activity}

Anemia is the most common blood disorder as it decreases the total amount of red blood cells or haemoglobin in the blood. Aqueous extract of Syzygium cumini seed was reported to increase the total haemoglobin, preventing and lowering the bodyweight and free radical formation in tissue (Sah and Verma, 2011).

\section{Antidiabetic activity}

Diabetes mellitus is a silent killer disease and other than insulin, this disorder can be controlled with the plant sources. The seeds of Syzygium cumini (L.) are recommended widely in many medical systems for controlling diabetes. Antidiabetic effect of seeds has also been proved by many pharmacological studies and their mode of action is represented in Figure 2. Acute in-vivo studies of ethanol extract $(100 \mathrm{mg} / \mathrm{kg}$ p.o.) of Syzygium cumini seeds in alloxan-induced diabetic rats 
showed a decrease in serum glucose level by $88 \mathrm{mg} / \mathrm{dl}$ as compared to Gibenclamide (97mg/dl) (Bansode et al., 2017). In another study, in-vivo antidiabetic activity of chloroform, methanol and aqueous extracts of Syzygium cumini seeds were assessed histologically in streptozotocin (STZ) induced diabetic mice and the results revealed restoration of normoglycemia, increase in G6PD, Plasma insulin and C-Peptide levels in the chloroform extract (Dusane and Joshi, 2011). Mycaminose, a deoxy-amino sugar isolated from the aerial parts of Syzygium cumini were evaluated for antidiabetic activity and alcoholic extract of seed powder was also reported to show hypoglycemic effect in Streptozotocin induced diabetic rats at a dosage level of $50 \mathrm{mg} / \mathrm{kg}$ body weight (Kumar et al., 2008). Inorganic metals of the alcoholic extract of Eugenia jambolana (Lam.) flower showed a decrease in the blood glucose level in nicotinamide-streptozotocininduced diabetic rabbits by $78.2 \mathrm{mg} / \mathrm{dl}$ after 30 days supplementation at a dosage of $100 \mathrm{mg} / \mathrm{kg}$ of body weight (Nisa and Malik, 2010). Ethanolic extract of Eugenia jambolana (Lam.) seed stimulated the pancreatic B cells to secrete more insulin and increased the insulin sensitivity in peripheral tissues i.e. adipose tissue, muscle, and liver, to clear blood glucose at a faster rate due to presence of $12 \%$ flavonoids (Yadav et al., 2010).

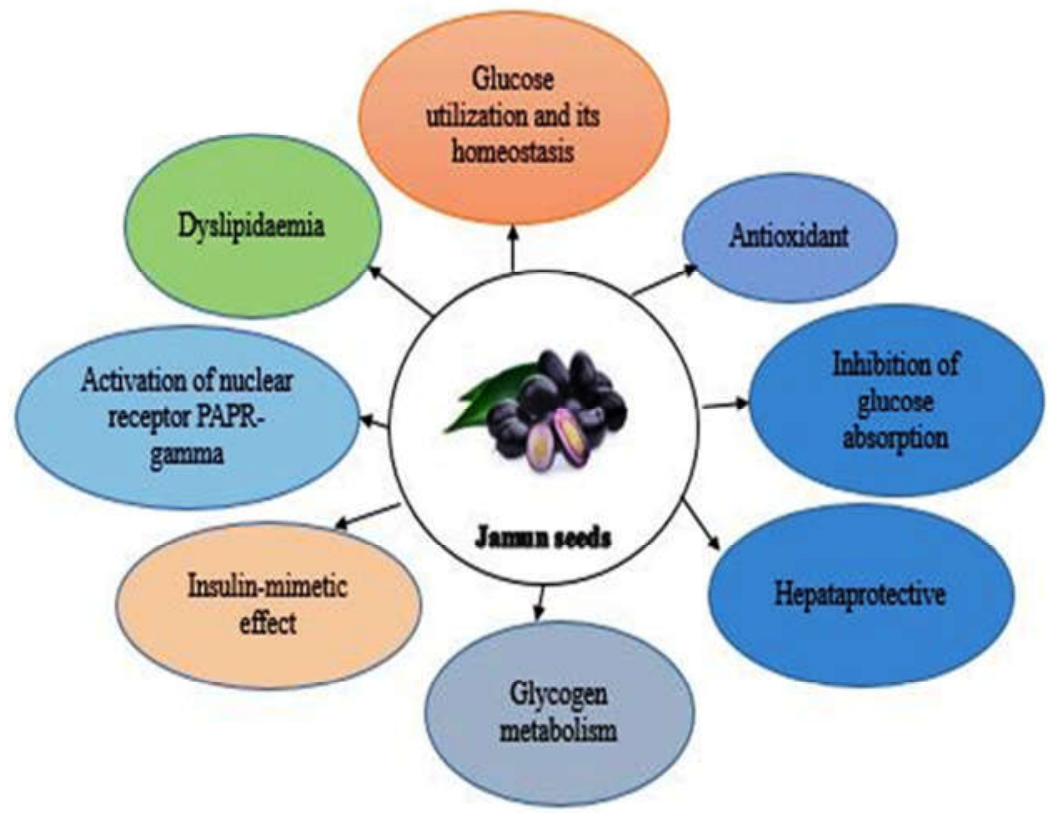

Figure 2. Mode of action of Syzygium cumini seeds as anti-diabetic agent

\section{Anti-diarrheal activity}

Antidiarrheal, antimotility and antisecretory activity of aqueous extract of Syzygium cumini seed was also studied by using the method of castor oil, charcoal meal test and castor oil induced intestinal secretions in mice and the extract showed 
antidiarrheal activity with inhibition of $42.85 \%$ at a dose level of $500 \mathrm{mg} / \mathrm{kg}$, antimotility activity with inhibition of $38.89 \%$ at a dose level of $500 \mathrm{mg} / \mathrm{kg}$ and antisecretory activity with inhibition of $51.61 \%$ at a dose level of $500 \mathrm{mg} / \mathrm{kg}$ (Shamkuwar et al., 2012). In another study, the ethanol extract of Syzygium cumini bark reduced diarrhoea in rats when given an oral dose of $400 \mathrm{mg} / \mathrm{kg}$ by inhibiting gastrointestinal motility (45.1\%) (Mukherjee et al., 1998). Seed powder prepared by mixing Eugenia jambolana (Lam.) seed with jaggery helps to get relief from diarrhoea and dysentery (Bhowmik et al., 2013).

\section{Antioxidant activity}

Oxidative stress is characterized by increased lipid peroxidation and a number of chronic complications of diabetes. Further, it occurs due to the depletion of antioxidant scavenger which creates an imbalance between free radical generation (Binita et al., 2017). Further, quercetin modifies the antioxidant defense pathways and inhibits lipid peroxidation either by directly scavenging free radicals or by inhibiting biomolecule oxidation. Antioxidants prevent free-radicals $\left(\mathrm{O}_{2}\right.$ and $\left.\mathrm{H}_{2} \mathrm{O}_{2}\right)$ and generate hydroxyl radicals for the acceleration of lipid peroxidation and decrease the activities of superoxide dismutase (SOD) and catalase (CAT) which further are responsible for several diseases and accelerate aging. Activities of these enzymes in diabetic brain increases after oral administration of aqueous extract of Syzygium cumini seed and alcoholic extract helped to restore them to the normal level. Further, more superoxide dismutase helped to reduce the toxic effects of superoxide radicals whereas CAT protected tissues from highly reactive hydroxyl radicals. The methanolic extract of Syzygium cumini showed total phenolic content of $17.6 \mathrm{mg} / \mathrm{g}$ in leaf, $16.1 \mathrm{mg} / \mathrm{g}$ in seed and $8.7 \mathrm{mg} / \mathrm{g}$ in pulp and flavonoid content of $43.24 \mathrm{mg} / \mathrm{g}$ in leaf, $19.1 / \mathrm{g}$ in seed and $12.27 \mathrm{mg} / \mathrm{g}$ in pulp (Margaret et al., 2015). Methanolic extract of leaves possesses an antioxidant property at a concentration of $106.34 \mathrm{ug} / \mathrm{mL}$ with $\mathrm{IC}_{50}$ value of $0.584 \pm 4.0 \mu \mathrm{g} / \mathrm{mL}$ of DPPH assay (Kumar and Kalakoti, 2015). In-vitro antioxidant activity of methanolic extract of the bark and fruit skin using 2,2-diphenyl-1-picrylhydrazyl (DPPH) scavenging assay, lipid peroxidation, ABTS assay, hydrogen peroxide scavenging assay, and ferric reducing antioxidant power (FRAP) assay has also been reported (Haroon et al., 2015).

\section{Hepatoprotective activity}

Hepatoprotective activity of methanol extract of Syzygium cumini seeds was investigated in rats at different doses for 14 consecutive days with group-I (control), group-II (silymarin treated; $1.0 \mathrm{mg} / \mathrm{kg} \mathrm{BW}$ ), group-III (extract of Syzygium cumini seeds treated; $250 \mathrm{mg} / \mathrm{kg}$ ), group-IV (extract treated; $500 \mathrm{mg} / \mathrm{kg}$ ) and group- $\mathrm{V}\left(\mathrm{CCl}_{4}\right.$ treated; $\left.1.5 \mathrm{mg} / \mathrm{kg}\right)$. An oral dose of $\mathrm{CCl}_{4}(1.5 \mathrm{mg} / \mathrm{kg}, 1: 1 \mathrm{in}$ olive oil) was administered to all the groups, except animals in the control group and after $24 \mathrm{~h}$ blood samples and liver tissues were collected for biochemical analysis. The values of liver function were found to be significantly lower while serum protein level was significantly higher in control and treated groups as compared to that of the $\mathrm{CCl}_{4}$ treated group (Islam et al., 2015). The alcoholic extract of the pulp of Eugenia jambolana (Lam.) exhibited a significant 
hepatoprotective action on paracetamol (PCM)-induced hepatotoxicity in albino rats when given at a dose level of 100 and $200 \mathrm{mg} / \mathrm{kg} /$ day. The results showed a decrease in the serum levels of ALT (alanine aminotransferase), AST (aspartate aminotransferase), ALP (alkaline phosphatase) and a reduction in fibrosis and necrosis (Das and Sarma, 2009). The fruit of the plant is a rich source of anthocyanins. The Syzygium cumini peel extract was reported to suppress $\mathrm{CCl}(4)$ induced LDH (Lactate dehydrogenase) leakage by $54 \%$ at $50 \mathrm{ppm}$ in rats and further, improving the cell viability by $39 \%$ (Veigas et al., 2008). Aqueous leaf extract (Moresco et al., 2007) and methanolic seed extract of Eugenia jambolana (Lam.) were also reported to show hepatoprotective effects through biochemical estimations and histopathological studies (Sisodia and Bhatnagar, 2009). Sidana et al., 2016 noticed significant reduction in the cholesterol levels from $220 \pm 33.60 \mathrm{mg} / \mathrm{dl}$ to $199 \pm 30.85 \mathrm{mg} / \mathrm{dl}$ and $190 \pm 28.81 \mathrm{mg} / \mathrm{dl}$ and a reduction in triglyceride levels from baseline of $183 \pm 39.19 \mathrm{mg} / \mathrm{dl}$ to $169 \pm 36.08 \mathrm{mg} / \mathrm{dl}$ and $161 \pm 34.71 \mathrm{mg} / \mathrm{dl}$ after 60 and 90 days of supplementation with Syzygium cumini seed powder and a percentage reduction by $8.28 \%$ and $13.66 \%$ respectively.

\section{Immunomodulatory activity}

The expression immune-modulatory means regulation of the immune system by suppression and stimulation of cells and organs of the immune system. Immunomodulatory therapy could be used as an alternative to conventional chemotherapy towards a variety of diseases. In- vitro study on the immunomodulatory effects on AAPH-induced damage in lymphocytes was conducted using the aqueous extracts of leaves and seeds of Syzygium cumini and the extracts are extracts were reported to exhibit antioxidant activity, prevent the increase of ectonucleotidase and adenosine deaminase (ADA) activities, inhibit acetylcholinesterase (AChE) activity, decrease lipoperoxidation and improvement in the cellular viability (Borges et al., 2017).

\section{Neuro-psychopharmacological activity}

Neuropharmacology is the methodology to study the effect of the functional component on the central nervous system with respect to biochemical and behavioral changes. Depressants are often prescribed by doctors to patients suffering from anxiety. The aqueous and ethanol extract of Syzygium cumini stem were observed by Sharma et al., (2017) on rat pheochromocytoma (PC)-12 cell line, by giving neurotoxic shock to Rat PC-12 cells using 6-hydroxydopamine. The ethanolic extract $(75 \%)$ showed the maximum number of viable cells as compared to aqueous extract $(50 \%)$. The chloroform extract of the seeds was also reported to possess central nervous system depressant action on rats by exhibiting variation in the general behavior pattern, reduction in spontaneous motility, hypothermia, muscle relaxation and suppression of aggressive behavior (Chakraborty et al., 1986). Oral treatment of hydro alcoholic extract showed anticonvulsant activity in pentylenetetrazol and maximum electroshock-induced convulsions besides a hypothermic effect due to the presence of active compounds present in the Syzygium cumini (Lima et al., 1998). Ethyl acetate and methanol extracts of the seeds at the dose level of $200 \mathrm{mg} / \mathrm{kg}$ and $400 \mathrm{mg} / \mathrm{kg}$ were reported to exhibit central 
nervous system depressant action in Albino mice due to the presence of saponins (Kumar et al., 2007).

\section{Anti-diuretic activity}

Diuretics are drugs that increase the excretion of water and sodium ions. The frequently occurring side effects by using diuretics drugs are headache, nausea, dizziness, loss of appetite, gout, rheumatoid arthritis and joint pain in severe cases (Chandrasekar and Sivagami, 2017). The diuretic activity and mechanism of action were evaluated using the methanolic extract of Syzygium cumini seeds in male Wistar albino rats and it was reported that the oral administration of methanolic extract $(300 \mathrm{mg} / \mathrm{kg})$ in association with Lornoxicam $(3 \mathrm{mg} / \mathrm{kg})$ reduced the urinary sodium, potassium, and chlorine excretion as when compared to the methanol extract (Venkateshwarlu et al., 2015). Different extracts prepared using chloroform, methanol and aqueous extracts were used to study the diuretic activity of Syzygium cumini and were administered orally at a dose of $500 \mathrm{mg} / \mathrm{kg}$. The methanol and aqueous extract possess the diuretic activity and showed an increase in total urine output and excretion of the electrolyte concentrations of sodium and potassium ions as compared to standard drug furosemide which was administered at a dose of $10 \mathrm{mg} / \mathrm{kg}$ body weight (Chandravarkar and Desai, 2014).

\section{Radioprotective activity}

Intraperitoneal administration of $80 \mathrm{mg}$ hydro alcoholic extract of Syzygium cumini seed $/ \mathrm{kg}$ body weight in mice showed a reduction in the symptoms of radiation sickness (Jagetia et al., 2005). Histological examination of mouse jejunum exposed to $7,10,15$ Gy gamma radiation was studied using leaf extract $(50 \mathrm{mg} / \mathrm{kg}$ body weight) of Syzygium cumini and the results revealed that the extract had provided protection against radiation induced intestinal mucosal damage in the small intestine and gastrointestinal damage (Jagetia et al., 2008).

\section{Toxicity}

The acute toxicity is the toxicity produced by a substance when administered in one or more doses during a period not exceeding 24hours. The hydro-alcoholic seed extract of Syzygium cumini and its phytosome formulation were evaluated against streptozotocin-induced diabetic rats for the acute toxicity, oral glucose tolerance test (OGTT) and anti-diabetic activity and the results showed no mortality and morbidity at a dose of $2000 \mathrm{mg} / \mathrm{kg}$ of body weight and also control in blood sugar level in comparison with standard drug Glibenclamide (Amudha et al., 2018). 70\% methanolic extract of leaf and stem bark of Syzygium cumini was evaluated for their acute toxicity studies in mice and the leaf extract was reported to produce a lower $\mathrm{LD}_{50}$ of $3,873 \mathrm{mg} / \mathrm{kg}$ compared to the stem bark which was $5000 \mathrm{mg} / \mathrm{kg}$ (Ugbabe et al., 2010). In another study, anti-diabetic potential of albino mice was evaluated for acute toxicity using methanol and aqueous extracts of leaves, seeds, barks, and roots of Syzygium cumini. The results revealed a significant reduction in blood glucose levels in mice when orally administered at a level of 50 and $100 \mathrm{mg} / \mathrm{kg}$ (Deb et al., 2013). The phytochemical analysis and oral acute toxicity of aqueous extract of stem and bark 
were investigated. The phytochemical screening revealed the presence of flavonoids, tannins, carbohydrates, sterols and amino acids. However, no signs of toxicity and mortality were detected while examining the oral acute toxicity during the study period of 14 days at a dose level of $5000 \mathrm{mg} / \mathrm{kg}$ body weight and no significant alteration in body weight, organ weight and hematological parameters were reported when compared to control group (Prasad et al., 2016).

\section{Use of Syzygium cumini as a functional ingredient in food products}

Seed, a waste obtained in excess amounts from Syzygium cumini processing is a rich source of nutrients. The fruits are processed to form various fermented, nonfermented beverages, jams etc. Besides that, good quality products can be prepared by incorporating seed powder. Different products are prepared using seed powder. Biscuits are a form of confectionery and are very convenient and inexpensive food products. In recent years, the consumption is increasing among rural and urban populations especially among children as well as aged persons at around $8-10 \%$ annually. Incorporation of jamun seed powder into biscuits reduces the rise in the blood glucose level and improves glycemic control (Kannan and Puraikalan, 2015). Patil et al., (2014) studied the sensory evaluation of biscuits supplemented with soy flour and jamun seed powder and found that biscuits prepared with $32 \%$ soy flour and $8 \%$ jamun seed powder gave the highest overall acceptability and was found significantly superior to other formulations. Similarly, Kalse et al., 2016 prepared biscuits using $81 \%$ wheat flour, $9 \%$ jamun seed powder, $10 \%$ finger millet had gain overall acceptability, with a density of $0.347 \mathrm{~g} / \mathrm{cc}$, calorific value of 482.68 $\mathrm{kcal} / 100 \mathrm{~g}$ and hardness value of $4535 \mathrm{~g}$ by textural analysis. The effect of fortification of seed powder in cookies at the concentration of $0,5,10,15 \%$ were studied by Desai et al., 2018 using 15\% finger millet flour. Cookies were subjected to organoleptic and nutritional quality analysis. The cookies prepared by the addition of $10 \%$ seed powder and $15 \%$ finger millet flour attained the highest acceptability with moisture (4.87\%), fat (13.49\%), fiber (1.73\%), protein $(9.47 \%)$, ash $(1.11 \%)$ and carbohydrate (69.25\%). Kannan and Puraikalan, (2015) formulated the cookies by incorporating seed powder at different levels $5 \%, 10 \%$ and $15 \%$. The results obtained revealed that cookies incorporated with $10 \%$ jamun seed powder showed higher acceptability. Noodle is a form of pasta that is becoming extremely popular in India and has become internationally recognized food. (Sood et al., 2018) prepared noodles by blending seed powder in $2 \%, 4 \%$, $6 \%, 8 \%, 10 \%$ level and the studied cooking attributes such as optimum cooking time, volume increase, weight increase, cooking loss and sensory properties. The cooking time decreased with the increase in the addition of seed powder. The weight increase of 141.42 to $174.52 \%$ was reported with the highest in control noodles. There is an increase in the volume of cooked noodles from 140 to $210 \%$. The highest cooking loss of $7.03 \%$ was observed in control sample and lowest was observed in $10 \%$ seed powder blended noodles. Noodles incorporated with $8 \%$ jamun seed powder were highly acceptable. Harine and Janapriya, (2018) prepared dhal adai mix powder as represented in using ingredients such as parboiled rice $(75$ g), Bengal gram dhal (5 g), green gram dhal (5 g), red dhal (5 g), red chilli with 
varying proportions of seed powder $(2 \%, 4 \%$ and $6 \%)$. The results of the study revealed that dhal adai mix powders incorporated with $4 \%$ of seed powder is mostly acceptable by the panel members and the nutritive value was also high when compared with the control with a protein content $(9.76 \mathrm{~g})$, carbohydrates $(72.42 \mathrm{~g})$, fiber content $(1.21 \mathrm{~g})$ and iron content $(1.8 \mathrm{mg})$. Further, the development of dhal adai mix powder contributes to the reduction of blood glucose levels when consumed by diabetic patients. Kasthuri et al., (2017) used Jamun seed powder and drumstick leaf powder which are a source of natural antioxidant and natural preservative with added health benefits for the development of functional chicken chips at different levels of $(1,2$ and $3 \%)$. The results showed that chicken chips containing $1 \%$ drumstick leaf powder and $1 \%$ jamun seed powders were highly acceptable.

\section{Conclusion}

Plants are the most exclusive source of drugs for a majority of the population as they provide efficient, safe and cheap medications for rural areas. Syzygium cumini is widely distributed and is used as a traditional medicine in different regions of the world. A high number of constituents have been extracted both from the aerial as well as underground parts of the plant using various solvents. The presence of numerous phytochemicals (anthocyanins, ellagic acid, citric acid, quercetin etc.) gives this plant various pharmacological properties such as antidiabetic, antioxidant, anti-inflammatory, anticancer, antifungal, antibacterial, antimicrobial, antipyretic, and antiulcer. The extracts of the plants are also used in the treatment of diarrhoea and dysentery, cancer, diabetes, alzheimer, stress etc. Most of the biological effects can be explained by the high amounts of tannins present in them such as antiviral, antimicrobial, hepatoprotective and anti-inflammatory effects. Further, fortification of the food with the various parts of the plant can also be one of the alternatives to utilize the plant along with increasing the medicinal properties of these foods. Hence, in the present review, the literature pertaining to phytochemical, pharmacological activities and medicinal uses has been given comprehensively.

\section{Acknowledgement}

The authors acknowledge the support provided by School of Bioengineering \& Food Technology, Shoolini University, Solan, India in getting the literature from different sources.

\section{References}

Amudha, S., Prabal, K.M., Jeganathan, N.S. 2018. Evaluation of anti-diabetic activity of Syzygium cumini extract and its phytosome formulation against streptozotocin-induced diabetic rats. The Pharma Innovation Journal, 7, 603-608.

Anjali, V., Sindhu, G., Girish, C. 2017. A review on pharmacology and phytochemistry of Syzygium cumini. Indian Journal of Pharmacy and Biological Research, 5, 24-28. 
Anonymous., 2013. Potential of commercial cultivation of Jamun. http://www.krishisewa.com/articles/production technology/353 jamun.html. Accessed. 2.12.2013.

Arun, R., Prakash, M.V., Abraham, S.K., Premkumar, K. 2011. Role of Syzygium cumini seed extract in the chemoprevention of in vivo genomic damage and oxidative stress. Journal of Ethnopharmacology, 134, 329-33.

Arya, V., Gupta, V.K., Kaur, R. 2011. A review on plants having anti-arthritic potential. International Journal of Pharmaceutical Science Review and Research, 7, 131-136.

Ayya, N., Nalwade, V., Khan, T.N. 2015. Effect of jamun (Syzygium cumini L.) seed powder supplementation on blood glucose level of type-II diabetic subject. Food science research journal, 6, 353-356.

Ayyanar, M., Babu, P.S., Ignacimuthu, S. 2013. Syzygium cumini (L.) Skeels. A novel therapeutic agent for diabetes: folk medicinal and pharmacological evidences. Complementary Therapies in Medicine, 21, 232-243.

Ayyanar, M., Babu, P.S. 2012. Syzygium cumini (L.) Skeels: A review of its phytochemical constituents and traditional uses. Asian Pacific journal of tropical biomedicine, 2(3), 240-246.

Ayyanar, M., Sankarasivaraman, K., Ignacimuthu, S. 2008. Traditional herbal medicines used for the treatment of diabetes among two major tribal groups in south Tamil Nadu, India. Ethnobotanical Leaflets, 12, 276-280.

Bag, A., Rabi, N.K.P., Chattopadhyay, R. 2012. In vitro antibacterial potential of Eugenia jambolana seed extracts against multidrug-resistant human bacterial pathogens. Microbiological Research, 167, 352-357.

Balyan, U., Sarkar, B. 2017. Aqueous extraction kinetics of phenolic compounds from jamun (Syzygium cumini L.) seeds. International journal of food properties, 20, 372389.

Bandiola, T.M.B., Ignacio1, G.B., Yunson, E.G.A., Bandiola, P.D.B. 2017. Syzygium cumini (L.) skeels: A review of its phytochemical constituents, toxicity and traditional and pharmacological uses. International journal of Applied Pharmaceutical and Biological Research, 2, 15-23.

Bansode, T.S., Salalkar, B.K., Dighe, P., Nirmal, S., Dighe, S. 2017. Comparative evaluation of antidiabetic potential of partially purified bioactive fractions from four medicinal plants in alloxan-induced diabetic rats. Pharmacological Study, 38, 165-70.

Barh, D., Vishwanathan, G. 2008. Syzygium cumini inhibits growth and induces apoptosis in cervical cancer cell lines: A preliminary study. E cancer medical science, 2, 1-9.

Bhowmik, D., Gopinath, H., Kumar, B.P., Kumar, K. 2013. Traditional and medicinal uses of Indian black berry. Journal of Pharmacognosy and Phytochemistry, 1, 36 -41.

Bhusari, M.R. 2014. Antibacterial activity of Syzygium Cumini L. (Jambhul) seed extract against pathogenic bacteria. International Journal of Scientific Research, 3, 505-506.

Bijauliya, R.K., Alok, S., Sabharwal, M., Chanchal, D.K. 2017. Syzygium cumini (Linn.) An overview on morphology, cultivation, traditional uses and pharmacology. International Journal of Pharmaceutical Science \& Research, 9, 3608-3620.

Binita K., Veena, S., Savita, Y. 2017. The therapeutic potential of Syzygium cumini seeds in diabetes mellitus. Journal of Medicinal Plants Studies, 5, 212-218. 
Borges, R.M., Bitencourt, P.E.R., Stein, C.S., Guilherme, V.B., Boligon, A., Rafael, N., Moresco, R.N., Moretto, M.B. 2017. Leaves and seeds of Syzygium cumini extracts produce significant attenuation of 2,2 azobis-2- amidinopropane dihydrochlorideinduced toxicity via modulation of ectoenzymes and antioxidant activities. Journal of Applied Pharmaceutical Science, 6, 37-48.

Chakraborty, D., Mahapatra, P.K., Chaudhuri, A.K. 1986. A neuro-psychopharmacological study of Syzygium cumini. Planta Medica, 52, 139-143.

Chandrasekar, R., Sivagami, B. 2017. Indian medicinal plants with diuretic activity. Indo American Journal of Pharmaceutical Research, 7, 7359-7380.

Chandrasekaran, M., Venkatasalu, V. 2004. Antibacterial and antifungal activity of Syzygium jambolanum seeds. Journal of Ethnopharmacology, 91, 105-108.

Chandravarkar, S., Desai, S.N. 2014. Diuretic activity of different extracts of bark of Syzygium cumini (Linn.) skeels. International journal of research in Ayurveda and Pharmacy, 5, 102-104.

Chaturvedi, A., Bhawani, G., Agarwal, P.K., Goel, S., Singh, A. Goel, R.K. 2009. Antidiabetic and antiulcer effects of extract of Eugenia jambolana seed in mild diabetic rats: study on gastric mucosal offensive acid-pepsin secretion. Indian Journal of Physiology \& Pharmacology, 53, 137-146.

Chhikara, N., Kaur, R., Jaglan, S., Sharma, P., Gat, Y., Panghal, A. 2018. Bioactive compounds and pharmacological and food applications of Syzygium cumini- a review. Food \& Function, 9(12), 6096-6115.

Chitnis, K.S., Palekar, S.B., Koppar, D.R., Mestry, D.Y. 2012. Evaluation of Syzygium cumini seed formulsations available in the market using spectrophotometric and chromatographic techniques. International Journal of Pharmaceutical Science and Research, 3, 556-560.

Dagadkhair, C.A., Pakhare, N.K., Todmal, D.A., Andhale, R.R. 2017. (Syzygium cumini) Skeels: A traditional therapeutic tree and its processed food products. International journal of Pure and Applied Bioscience, 5, 1202-1209.

Damasceno, D.C., Volpato, G.T., Calderon, I.D., Rudge, C.V.C. 2002. Study of Averrhoa carambola and Eugenia jambolana extracts purchased from manipulation drug store on the experimental diabetes. Revista Brasilera de Toxicology, 1, 9-14.

Das, S., Sarma, G. 2009. Study of the hepatoprotective activity of the ethanolic extract of the pulp of Eugenia jambolana (jamun) in albino rats. Journal of Clinical and Diagnostic Research, 3, 1466-1474.

Deb, L., Bhattacharjee, C., Shetty, S.R., Dutta, A. 2013. Evaluation of anti-diabetic potential of the Syzygium cumini (Linn.) skeels by reverse pharmacological approaches. Bulletin of Pharmaceutical Research, 3, 135-45.

Desai, G.B., Sawate, A.R., Taur, A.T., Thorat, P.P., Deshmukh, N.M., Kshirsagar, R.B., Patil, B.M. 2018. Effect of fortification of Jamun Seed (Syzygium cumini) powder on nutritional and sensory quality of herbal multigrain cookies. International Journal of Chemical Studies, 6, 1083-1087.

Dusane, M.B., Joshi, B.N., Chin. J. 2011. Seeds of Syzygium cumini (Skeels): potential for islet generation in experimental diabetes. Journal of Integrative Medicine, 9, 13801387. 
Margaret, E., Shailaja, A.M., Venugopal Rao, V. 2015. Evaluation of antioxidant activity in different parts of Syzygium cumini (Linn.). International Journal of Current microbiology and Applied Sciences, 4(9), 372-379.

El-Safy, F.S., Salem, R.H., Abd El-Ghany, M.E. 2012. Chemical and nutritional evaluation of different seed flours as novel sources of protein. World Journal of Dairy and Food Sciences, 1, 59-65.

Ezekiel, U., Heuertz, R. 2015. Anti-inflammatory effect of Syzygium cumini on chemotaxis of human neutrophils. International Journal of Pharmacology, Phytochemistry Research, 7, 714-717.

Ghosh, P., Pradhan, C.R., Mishra, S., Patel, S.A., Kar, A. 2016. Physicochemical and nutritional characterization of Jamun (Syzygium Cuminii). Current Research in Nutrition and Food Science, 5, 25-35.

Gowri, S.S., Vasantha, K. 2010. Phytochemical screening and antibacterial activity of Syzygium cumini (L.) (Myrtaceae) Leaves Extracts. International Journal of Pharm Tech Research, 2, 1569-1573.

Goyal, P.K., Verma, P., Sharma, P., Parmar, J., Agarwal, A. 2010. Evaluation of anticancer and anti-oxidative potential of Syzygium cumini against benzo[a]pyrene (BaP) induced gastric carcinogenesis in mice. Asian Pacific journal of cancer prevention, 11, 753758.

Haque, R., Sumiya, M.B., Sakib, N., Sarkar, O.S., Siddique, T.T., Hossain, S., Islam, A., Parvez, A.K., Talukder, A.A., Dey, S.K. 2017. Antimicrobial activity of Jambul (Syzygium cumini) fruit extract on enteric pathogenic bacteria. Advances in Microbiology, 7, 195-204.

Harine, S.J., Janapriya, S. 2018. Development and acceptability of ready-mix powders incorporated with Jamun seed (Syzygium cumini) powder for diabetic patients. International Journal of Current Advanced Research, 7, 10792-10795.

Haroon, R., Jelani, S., Arshad, F.K. 2015. Comparative analysis of antioxidant profiles of bark, leaves and seeds of Syzygium cumini (Indian blackberry). International Journal of research-Granthaalayah, 3, 13-26.

Hofling, J.F., Anibal, P.C., Obando-Pereda, G.A., Peixoto, I.A.T, Furletti, V.F, Fogli, M.A., Gonçalves, R.B. 2010. Antimicrobial potential of some plant extracts against Candida species. Brazilian Journal of Biology, 70, 1065-1068.

Hossain, S., Islam, J., Bhowmick, S., Haque, M., Rahaman, A. 2017. Effects of Syzygium cumini seed extract on the memory loss of alzheimer's disease model rats. Advances in Alzheimer's Disease, 6, 53-73.

Imran, M. Mohd, I., Khan, S. 2017. Antibacterial activity of Syzigium cumini leaf extracts against multidrug resistant pathogenic bacteria. Journal of Applied Pharmaceutical Science, 7, 168-174.

Islam, M., Hussain, K., Latif, A., Hashmi, F.K., Saeed, H., Bukhari, N.I. 2015. Evaluation of extracts of seeds of Syzygium cumini L. for hepatoprotective activity using $\mathrm{CCl}_{4}$ induced stressed rats. Pakistan Veterinary Journal, 35,197-200.

Jadhav, V.M., Kamble, S.S., Kadam, V.J. 2009. Herbal medicine: Syzygium cumini: A Review. Journal of Pharmacy Research, 2, 1212-1219.

Jagetia, G.C., Baliga, M.S., Venkatesh, P. 2005. Influence of seed extract of Syzygium cumini (Jamun) on mice exposed to different doses of $\gamma$-radiation. Journal of Radiation Research, 46, 59-65. 
Jagetia, G.C. 2017. Phytochemical composition and pleotropic pharmacological properties of jamun, Syzygium cumini, Skeels. Journal of exploratory research in pharmacology, 2, 54-66.

Jagetia, G.C., Shetty, P.C., Vidyasagar, M.S. 2008. Treatment of mice with leaf extracts of jamun protects against the radiation induced damage in the intestinal mucosa of mice exposed to different doses of gamma radiation. Pharmacology Online, 1, 169-195.

Jain, S.K. 1991. Dictionary of Indian Folk medicine and ethnobotany. Deep Publications Paschimvihar, New Delhi.

Janick, J., Paull, R.E. (2008). The encyclopedia of fruits and nuts. CAB International, Wallingford, UK.

Jonnalagadda, A., Maharaja, K.K., Kumar, P. 2013. Combined effect of Syzygium cumini seed kernel extract with oral hypoglycemics in diabetes induced increase in susceptability to ulcerogenic stimuli. Journal of Diabetes and Metabolism, 4, 1-6.

Julie, A.S., Sultana, T., Laboni, F.R., Karim, S., Labu, Z.K. 2017. In-vitro Investigation of Biological Activity of Aerial Part of Syzygium cumini. International Journal of Applied Pharmaceutical and Biological Research, 2, 34-38.

Kalse, S.B., Swami, S.B., Sawant, A.A., Thakor, N.J. 2016. Development and quality evaluation of Jamun seed powder fortified biscuit using finger millet. Journal of Food Processing and Technology, 7,1-3.

Kannan, A., Puraikalan, Y.D. 2015. Development and effects of jamun seed powder incorporated cookies. International Journal of Pharmacognosy and Phytochemical Research, 5, 1934-1935.

Kasiappan, R., Subbaih, R., Sorimuthu, S. 2005. Antihyperlipidemic effect of Eugenia jambolana seed kernel on streptozotocin-induced diabetic rats. Food and Chemical Toxicology, 243, 1433-1439.

Kasthuri, S., Mandal, P.K., Pal, U.K., Elanchezhian, N., Perumal, S.V. 2017. Effect of incorporation of drumstick leaf and jamun seed powder on sensory quality of functional chicken chips. Journal of meat science, 12, 14-18.

Kaur, A., Singh, D., Kaur, H., Sogi, D.S. 2018. Drying characteristics and antioxidant properties of Java plum seed and skin waste. Journal of Stored Products and Postharvest Research, 9, 36-43.

Khan, A., Jabeen, K., Iqbal, S. 2016. Antifungal activity of Syzygium cumini L. against Rhizoctonia solani. Pure and Applied Biology, 5, 193-199.

Kharat, A.D., Deshpande, A.R., Mussadiq. 2005. Antifungal activity of some medicinal plants against two phytopathogenic fungi. Asian Journal of Microbiology, Biotechnology and Environmental Science, 7, 743-745.

Kumar, A. 2008. A study of therapeytic applications of the extracts of seeds of Syzygium cumini. Ph.D. Thesis. Dr. M.G.R. Educational and Research Institute University, Chennai.

Kumar, A., Ilavarasan, R., Jayachandran, T., Decaraman, M., Aravindhan, P. 2009. Phytochemicals investigation on a tropical plant, Syzygium cumini from Kattuppalayam, Erode District, Tamil Nadu, South India. Pakistan Journal of Nutrition, 8, 83-85. 
Kumar, A., Ilavarasan, R., Jayachandran, T., Deecaraman, M., Kumar, R.M., Aravindan, P.N., Padmanabhan, N., Krishan, M.R.V. 2008. Anti-inflammatory activity of Syzygium cumini seed. African Journal of Biotechnology, 7, 941-943.

Kumar, A., Kalakoti, M. 2015. Phytochemical and antioxidant screening of leaf extract of Syzygium cumini. International Journal of Advanced Research, 3, 371-378.

Kumar, A., Padmanabham, N., Krishnan, M.R.V. 2007. Central nervous system activity of Syzygium cumini seed. Pakistan Journal of Nutrition, 6, 698-700.

Kumar, D., Arora, S., Alam, M. 2014. Pharmacognostical standardization and antimicrobial activities of leaves of Syzygium cumini from various regions of India. International research journal of Pharmacy, 5, 62-65.

Kumari, K., Sharma, S., Kaushik, R. 2017. Wild Himalayan fig: A Nutraceutical under exploited fruit of western Himalayan region- A review. International Journal of Advanced Research, 5(9), 833-839.

Kumawat, M., Damor, J., Kachchhwaha, J., Garg, A.K., Singh, C. 2018. Pharmacological properties and therapeutic potential of Syzygium cumini (Jamun): A review. World Journal of Pharmaceutical Sciences, 7, 312-322.

Lima, T.C.M., Klueger, P.A., Pereira, P.A., Macedo-Neto, W.P., Morato, G.S., Farias, M.R. 1998. Behaviour effects of crude and semi-purified extracts of Syzygium cumini (Linn.). Phytotherapy research, 12, 488-493.

Mastan, S. K, Chaitanya, G., Latha, B.T., Srikanth, A., Sumalatha, G., Kumar, E.K. 2009. Cardioprotective effect of methanolic extract of Syzygium cumini seeds on isoproterenol-induced myocardial infarction in rats. Der Pharmacia Lettre, 1, 143-149.

Mathur, A. 2015. Extraction and characterization of Syzygium cumini (Jamun) seed oil. International Journal of Advance Research in Engineering, Science \& Technology, 2, 78-80.

Mathur, A., Purohit, R., Mathur, D., Prasad, G.B.S.K., Dua, V.K. 2011. Pharmacological investigation of methanol extract of Syzygium cumini seeds and Crateva nurvula bark on the basis of antimicrobial, antioxidant and anti-inflammatory properties. Der Chemica Sinica, 2, 174-181.

Meshram, G.A., Yadav, S.S., Shinde, D., Patil, B., Singh, D. 2011. Antibacterial study and effect of ethanolic extract of Syzgium cumini seeds powder on glucoamylase in vitro. Journal of pharmaceutical Sciences and Research, 3, 1060-1063.

Moresco, R.N., Sperotto, R.L., Bernardi, A.S., Cardoso, R.F., Gomes, P. 2007. Effect of the aqueous extract of Syzygium cumini on carbon tetrachloride-induced hepatotoxicity in rats. Phytotherapy Research, 21, 793-79.

Mukherjee, P., Saha, K., Murugeresan, T., Mandal, S.C., Pal, M., Saha, B.P. 1998. Screening of anti-diarrhoeal profile of some plant extracts of a specific region of West Bengal, India. Indian Journal of Ethnopharmacology, 60, 85-89.

Nisa, T.M., Malik, A.S. 2010. Anti-diabetic activity of inorganic metals of Eugenia Jambolana Lam. (Myrtaceae) flowers. Pharmacology, 2, 979-985.

Ogato, D.M., Mauti, E.M., Mauti, G.O., Kowanga, D.K., Ouno, G.A. 2015. Antimicrobial activity of Eugenia jambolana seeds against foodborne isolates. Journal of Scientific and Innovative Research, 4, 232-236. 
Panghal, A., Yadav, D.N., Khatkar, B.S., Sharma, H., Kumar, V., Chhikara, N. 2018. Postharvest malpractices in fresh fruits and vegetables: Food safety and health issues in India. Nutrition and Food Science, 4, 561-578.

Pant, O.P., Chandra, M., Sethi, S., Punetha, H., Dixit, S., Pant, A.K. 2014. Biochemical analysis, pharmacological activity, antifungal activity and mineral analysis in methanolic extracts of Myrica esculenta and Syzygium cumini: The Indian Traditional Fruits Growing in Uttarakhand Himalaya. Indian Journal of Pharmacy and Biological Research, 2, 26-34.

Parmar, J., Sharma, P., Verma, P., Goyal, P.K. 2010. Chemopreventive action of Syzygium cumini on DMBA induced skin papillomagenesis in mice. Asian Pacific Journal of Cancer Prevention, 11, 261-265.

Parmar, J., Sharma, P., Verma, P., Sharma, P., Goyal, P.K. 2011. Modulation of DMBAinduced biochemical and histopathological changes by Syzygium cumini seed extract during skin carcinogenesis. International Journal of Current Biomedical and Pharmaceutical research, 1, 24-30.

Parnell, J.A.N., Craven, L.A. Biffin, E. 2007. Matters of scale dealing with one of the largest genera of Angiosperms. In: Hodkinson, T. \& Parnell, J. (eds.) Reconstructing the Tree of Life, Taxonomy and Systematic of Species Rich Taxa. The Systematics Association, Taylor \& Francis, Boca Raton, 251-273.

Patel, S., Shanmugarajan, T.S., Somasundaram, I., Maity, N. 2010. Protective effect of Syzygium cumini seeds against doxorubicin induced cardiotoxicity in rats. International Journal of Current Pharmaceutical Research, 1, 343-349.

Patil, M., Kalse, S.B., Jain, S.K. 2014. Sensory evaluation of biscuits supplemented with soy flour and jamun seed powder. International journal of Pharmacy and Life Science, 7, 131-136.

Perera, P.R.D., Ekanayake, S., Ranaweera, K.K.D.S. 2017. Antidiabetic Compounds in Syzygium cumini decoction and ready to serve herbal drink. Evidence Based Complementary and Alternative Medicine, 1083589. 1-5.

Prajakta, D., Sadawarte, Keshav, H.P., Sachin, K.S., Shalini, S.A. 2016. Potential Food Applications and Health Benefits of Jambhul (Syzygium cuminii L.). The Indian Journal of Nutrition and Dietetics, 53, 343-353.

Prasad, M., Venugopal, S.P., Alagarsamy, V., Sridevi, C. 2016. The Preliminary phytochemical analysis and oral acute toxicity study of stem bark of Syzygium cumini. International Journal of Pharmacy and Pharmaceutical Sciences, 8, 209-213.

Ramya, S., Neethirajan, K., Jayakumarara, J. 2012. Profile of Bioactive Compounds in Syzygium cumini- A Review. Journal of Pharmacy Research, 5, 4548-4553.

Ranjan, A., Jaiswal, A., Raja, R.B. 2011. Enhancement of Syzygium cumini (Indian Jamun) active constituents by ultra-violet (UV) irradiation method. Scientific Research and Essays, 6, 2457-2464.

Raza, A., Ali, U.M., Tanzeela, N.T., Qasrani, A.S., Hussain, R., Sharif, N.M. 2015. Proximate composition of jamun (Syzygium cumini) fruit and seed. American-Eurasian Journal of Agriculture \& Environment Science, 15, 1221-1223.

Rout, S.D., Panda, T. 2017. Ethnobotanical survey of medicinal plants used for the treatment of diarrhoea and dysentery by the tribals of Similipal forest, Mayurbhanj, Odisha, India. Applied Science Report, 19, 9-18. 
Roy, G., Malla, S., Chakravarty, S. 2013. Integrated processing of jamun (Syzygium cumini (L.) Skeels) fruit for value addition and assessment of its impact on health and nutrition, Archive of clinical and diagnostic laboratory immunology, 21, 65-69.

Ruthurusamy, S.K., Dheeba, B., Hameed, S.S., Palanisamy, S. 2015. Anti-cancer and antioxidative potential of Syzygium cumini against breast cancer cell lines. Journal of Chemical and Pharmaceutical Research, 7, 449-460.

Sah, A.K., Verma, V.K. 2011. Syzygium cumini: An overview. Journal of Chemical and Pharmaceutical Research, 3, 108-113.

Saleem, U., Ali, N., Ahmad, B. (2016). Does Syzygium cumini possess significant Pharmacological effects an Overview. Newsletter, 2, 26-29.

Satish, S., Raghavendra, M.P., Raveesha, K.A. 2008. Evaluation of the antibacterial potential of some plants against human pathogenic bacteria. Advances in Biological Research, 2, 44-48.

Satpute, S.B., Vanmare, D.J. 2018. Phytochemical screening of leaf extract of Syzygium Cumini L. by HRLC-MS spectra method. International Journal of Research Science and Technology, 4, 33-37.

Sehwag, S., Das, M. 2014. Nutritive, therapeutic and processing aspects of Jamun (Syzygium cumini) Skeels- An overview. Indian journal of natural products and resources, 5, 295-307.

Sen, S.K., Behera, L.M. 2008. Ethnomedicinal plants used by the tribals of Bargarh district to cure diarrhoea and dysentery. Indian Journal of Traditional Knowledge, 7, 425-428.

Shamkuwar, Prashant, B., Pawar, D.P., Chauhan, S.S. 2012. Antidiarrhoeal activity of seeds of Syzygium cumini L. Journal of Pharmacy Research, 5, 5537-5539.

Shareef, S.M., Santhosh Kumar, E.S., Shaju, T. 2012. A new species of Syzygium (Myrtaceae) from the southern Western Ghats of Kerala, India. Phytotaxa, 71, 28-33.

Shareef, S.M., Geetha Kumary, M.P., Santhosh Kumar, E.S. Shaju, T. 2010. Syzygium claviflorum (Myrtaceae) -A new record for South India. Rheedea, 20, 53-55.

Sharma, S.M., Mehta, B.K., Nagar, D., Mishra, A.H. 2012. A review on pharmacological activity of Syzygium cumini extracts using different solvent and their effective doses International Research Journal of Pharmacy, 3, 54-58.

Sharma, Y., Mehrotra, A., Kundu, N., Srivastava, N.S. 2017. A study of antibacterial, antioxidant and neuroprotective effect of stem of Syzygium cumini. International Journal of Green Pharmacy, 11, 236-243.

Sidana, S., Singh, V.B., Meena, B.L., Beniwal, S., Chandra, S., Singh, K., Singla, R., Kumar, D. 2016. Effect of Syzygium cumini (jamun) seed powder on dyslipidemia: a double-blind randomized control trial. International Journal of Research and Medical Science, 7, 2603-2610.

Singh, A., Navneet. 2018. Ethnobotanical uses, antimicrobial potential, pharmacological properties and phytochemistry of Syzygium cumini Linn- A review. International Journal of Innovative Pharmaceutical Science and Research, 6, 32-47.

Singh, R., Allaie, A.H., Ganaie, A.A., Mishra, R.V., Vyas, M., Ganaie, H.A., Shoket Ali, S. 2017. Antifungal activity of medicinal plants with special reference to antidermatophytic activity: A review. The Pharma Innovation Journal, 6, 251-259.

Sisodia, S.S., Bhatnagar, M. 2009. Hepatoprotective activity of Eugenia jambolana Lam in carbon tetrachloride treated rats. Indian Journal of Pharmacology, 41, 23-27. 
Sivasubramaniam, K., Selvarani, K. 2012. Viability and vigor of jamun (Syzygium cumini) seeds. Brazilian Journal of Botany, 35, 397-400.

Sood, M., Julie, D., Bandral, J.D., Kaur, M. 2018. Development and quality evaluation of jamun seed powder supplemented noodles. Journal of Pharmacognosy and Phytochemistry, 7, 1411-1416.

Swami, S.B., Singh, J.N.T., Meghatai, M.P., Parag, M.H. 2012. Jamun (Syzygium cumini) L.: A review of its food and medicinal uses. Food and Nutrition Sciences, 3, 11001117.

Tikadar, P., Palita, S.K., Panda, D. 2017. Phytochemical analysis of medicinal plants used for treatment of dysentery and diarrhoea by the Paraja Tribe of Koraput, Odisha, India. International Journal of Herbal Medicine, 5, 1-4.

Tripathy, G., Pradhan, D. 2015. In-vitro anti breast cancer activity of Syzygium Cumini against MCF-7 Cell Line. Journal of Innovations in Pharmaceuticals and Biological Sciences, 2, 119-124.

Ugbabe, G.E., Ezeunala, M.N., Edmond, I.N, Apev, J., Salawu, O.A. 2010. Preliminary phytochemical, antimicrobial, and acute toxicity studies of the stem bark and the leaves of cultivated Syzygium cumini Linn in Nigeria. African Journal of Biotechnology, 9, 6943-6947.

Veigas, J.M., Narayan, M.S., Laxman, P.M., Neelwarne, B. 2008. Efficient amelioration of carbon tetrachloride induced toxicity in isolated rat hepatocytes by Syzygium cumini Skeels extract. Toxicology in Vitro, 22, 1440-1446.

Venkataramanan, R.V., Raju, C.D., Sumithra, M., Prakash, M.P., Goswami, H. 2016. Evaluation of antirheumatic activity of petroleum ether extract of Syzygium cumini Stem Bark in Rats. Biomedical Pharmacy Journal, 9, 639-642.

Venkateshwarlu, B.S., Rao, S.B.R., Venkateshwar, E.G., Umasankar. 2015. Evaluation of diuretic activity of Syzygium cumini and its effect on prostaglandin system. Oriental Pharmacy and Experimental Medicine, 15, 45-51.

Yadav, A.K., Saraswat, S., Sirohi, P., Rani, M., Srivastava, S., Singh, M.S., Nand, K. 2017. Antimicrobial action of methanolic seed extracts of Syzygium cumini Linn. on Bacillus subtilis. AMB Express, 7, 196.

Yadav, M., Lavania, A., Tomar, R., Prasad, G.B.K.S., Jain, S., Yadav, H. 2010. Complementary and comparative study on hypoglycemic and antihyperglycemic activity of various extracts of Eugenia jambolana Seed, Momordica charantia Fruits, Gymnema sylvestre, and Trigonella foenum graecum seeds in rats. Applied Biochemistry and Biotechnology, 160, 2388-2400. 